\title{
Comparing alternative products in the provision of emergency contraception
}

John P. Skibiak

Yusuf Ahmed

M. Ketata

Follow this and additional works at: https://knowledgecommons.popcouncil.org/departments_sbsr-rh

Part of the Demography, Population, and Ecology Commons, Health Services Research Commons, International Public Health Commons, and the Women's Health Commons How does access to this work benefit you? Let us know!

\section{Recommended Citation}

Skibiak, John P., Yusuf Ahmed, and M. Ketata. 1999. "Comparing alternative products in the provision of emergency contraception," Africa OR/TA Project II Final Report. Nairobi: Population Council. 
Comparing alternative products in the provision of emergency contraception

Y. Ahmed, University Teaching Hospital

J. P. Skibiak, Population Council

M. Ketata, University Teaching Hospital 


\section{ABSTRACT}

This report is the third in a series of summaries produced in connection with the operations research project, Enhancing Access to Family Planning Services through the Introduction of Emergency Contraception. The project was launched in September 1997 to explore a broad range of issues surrounding the introduction and delivery of emergency contraception services in a developing country context.

The study described in this report compares the introduction of two different emergency contraception pills: the combined oral contraceptive $P C$-4, introduced into Zambia in 1997, and the progestin-only contraceptive, Postinor-2, which was introduced by this study in the following year. The impetus for the study evolved out of two concerns expressed at a 1998 national workshop on emergency contraception. The first was that Schering $A G$, the manufacturer of $P C-4$, might block moves to broaden the range of facilities providing the product, despite indications that doing so would make emergency contraception more accessible to thousands of Zambian women. Elsewhere, the manufacturer had prevented the registration of $P C-4$ on similar grounds, and it was feared that they might do so again in Zambia. The second impetus for comparing the two products was the growing body of evidence to suggest that progestin-only pills might actually be a better product than the combined oral regimen, both in terms of reducing side-effects and limiting the number of unwanted pregnancies. Service providers, therefore, were eager to see for themselves what impact, if any, a progestin-only alternative might have on improving overall quality of care.

Because Zambia's experience with emergency contraception had been, prior to this study, based solely on the delivery of $P C-4$, the objective of this research was to explore whether the lessons learned in connection with that product would still be applicable should circumstances necessitate the registration of an alternative emergency contraception pill. The goal of this exercise, therefore, was to provide an empirical basis for generalizing the lessons learned to date through the introduction of $P C-4$. To accomplish this, the study compared 1) differences in the service delivery requirements associated with the provision of the two methods; 2) variations in the range, frequency and/or severity of side effects attributable to the two methods; and 3) any discrepancies in client attitudes and behavior that might be method-related.

The research design entailed replicating activities previously undertaken to introduce $P C-4$, but among a different group of public-sector health care facilities in Lusaka. The study entailed three major sets of activities: provider training; the delivery of emergency contraception services; and the collection of service statistics and other data on potential and actual users of emergency contraception services. Results were then compared across the two groups of health care facilities.

Study results revealed that despite the earlier introduction of $P C-4$, clients at the two groups of facilities evidenced few differences in knowledge or attitudes. Both groups, for example, were equally likely to claim they knew ways of preventing a pregnancy after unprotected intercourse and equally unlikely to identify a correct response. Clients at the Postinor-2 clinics were no more likely than those at the $P C-4$ clinics either to recognize the name "emergency contraception", or to be aware that oral contraceptives could be used for emergency purposes. Given this lack of familiarity, the study recommended that a more systematic dissemination of information on the method be undertaken.

Acceptance rates of the two products followed similar trajectories. Both began gradually, peaked at around 4-6 months, and then leveled off. Although the volume of PC-4 distributed exceeded that of Postinor-2, the disparity was attributable to differences in the sizes of the two catchment areas, to provider concerns over the long-term availability of Postinor-2, and even to provider-preferences for $P C$-4 itself. Not only did many providers believe Postinor-2 to be "more experimental" than $P C-4$ but, in contrast to their clients, most providers were already familiar with $P C-4$ by the time the study had begun. Given the potential impact of such provider preferences, the study recommended that until Zambia's regulatory authorities selected an emergency contraception product for approval, IEC efforts should remain brand-neutral and focus more on the possibilities of preventing unwanted pregnancies, than on the technical or commercial attributes of any particular emergency contraception pill.

The second issue to be addressed in this study concerned the impact of reduced levels of side effects associated with use of Postinor-2 on client behavior and services. Of particular concern was the fear that a "more tolerable" emergency contraceptive method might remove incentives for women to shift to routine family planning methods. Overall, the results of this study suggest only a weak relationship between side effects and the 
adoption of routine family planning. Most emergency contraception users eventually adopted a routine family planning method, regardless of whether they used PC-4 or Postinor-2. With respect to the transition to 
more effective contraceptive methods, the similarities across groups once again outweighed differences. Among all women who returned for their follow-up visit and chose a family planning method, the adoption of highly effective, essentially hormonal methods, reached levels of 90 percent and above. Finally, regarding the attitudes of emergency contraception users towards the methods themselves, client histories showed only minor differences. Of the 59 Postinor-2 users who returned to follow up, only one said she would not recommend the method to a friend; the reason given being method failure. A slightly higher percentage of former $P C$ - 4 users said they would not recommend the method; but in both cases, method approval exceeded 95 percent.

The study concludes by arguing that, at the service delivery level, the similarities between $P C$ - 4 and Postinor-2 greatly overshadow their differences. Family planning users display few preferences or aversions towards either product. They adopt both at comparable rates and, after having used them, manifest few if any differences in their appreciation of either product; in their decision to adopt a family planning method, or even in their choice of method itself. From a provider-perspective, similarities also overshadow differences.

But the study also highlights important differences between the two products; some of which could very well have implications for the delivery of services. One such difference relates to supply and logistics. One advantage of a combined oral regimen is that it can always be substituted by regular oral contraceptives. In the event of product stockouts or in an environment of cost cutting, $P C$ - 4 can be replaced - and done so more cheaply - by existing supplies. Postinor-2, by contrast, has no true equivalent within the range of methods typically available at health care facilities. An entire cycle of minipills might offer the same level of hormones as a single tablet of Postinor-2, but it is not certain the progestins contained in them would be metabolized in the same way or even whether women would be willing to ingest an entire cycle of pills at one time. Furthermore, substitution would not provide any cost savings since the unit price of Postinor-2 and a cycle of minipills is essentially the same.

On the other hand, however, the study also points out some important shortfalls of the combined oral regimen the most notable being its comparatively high levels of side effects and its lesser efficacy at preventing pregnancies. As this study makes clear, no one factor alone will ever determine whether PC-4 or Postinor-2 represents the ideal product for the Zambian context. Cost, efficacy, level of side effects, flexibility in distribution, and the potential for donor procurement must all - to some degree -- enter into the equation. What the present study does show, however, is that in arriving at their decision, Zambia's health planners and regulatory authorities can build with confidence on the body of service delivery information accumulated since the introduction of $P C$-4. Though substantive differences between the two products do indeed exist, these differences do not call for new training programs, different client support mechanisms, or even distinctive strategies for the dissemination of information. 


\section{NOTE DE SYNTHESE}

Ce rapport est le troisième d'une série de comptes rendus produits dans le cadre d'un projet de recherche opérationnelle intitulé «Améliorer l'Accès aux Services de Planification Familiale à travers l'Introduction à la Contraception d'Urgence». Ce projet a été lancé en septembre 1997 afin d'étudier plusieurs points portant sur l'introduction et la prestation des services de contraception d'urgence dans le contexte d'un pays en voie de développement.

L'étude décrite dans ce rapport fait la comparaison de l'introduction de deux différentes pilules contraceptives d'urgence (PCU): le contraceptif combiné, PC-4, introduit en Zambie en 1997, et le contraceptif progestatif, Postinor-2, introduit par la présente étude l'année suivante. La décision d'entreprendre cette étude a répondu à deux préoccupations exprimées au cours d'un atelier national sur la contraception d'urgence, tenu en 1998. La première préoccupation était que Schering $\mathrm{AG}$, fabriquant de $P C$-4, pourrait faire obstruction aux démarches visant l'élargissement de la gamme des points d'offre du produit, même si en agissant ainsi, cela rendrait la contraception d'urgence plus accessible aux milliers de femmes. Le fabriquant avait déjà empêché la reconnaissance officielle de $P C-4$ dans d'autres pays et l'on craignait qu'il fasse de même en Zambie. La seconde motivation pour la comparaison des deux produits était cependant l'évidence suggérant que le régime progestatif pourrait être en réalité meilleur que le régime combiné, en termes de diminution aussi bien des effets secondaires que du nombre de grossesses indésirables. Les prestataires de services étaient donc curieux de constater par eux-mêmes quel impact ce régime alternatif pourrait avoir sur l'amélioration globale de la qualité des soins.

L'expérience de la Zambie en matière de contraception d'urgence ayant été ainsi basée jusque là sur l'approvisionnement en $P C$-4 uniquement, l'objectif premier de cette étude était de chercher à savoir si les leçons apprises de cette expérience seraient toujours applicables au cas où les circonstances nécessiteraient la reconnaissance d'une autre pilule contraceptive d'urgence. Le but de cette opération, par conséquent, était de fournir des bases empiriques visant à généraliser les leçons apprises avec l'introduction préalable de $P C$-4. Pour ce faire, l'étude a comparé les différences entre les conditions requises pour la prestation des deux méthodes; la gamme, la fréquence et/ou la gravité des effets secondaires liés à l'emploi des deux méthodes; et entre les conséquences de telles différences sur les attitudes ou comportement du client.

Le plan de recherche a consisté en la reproduction des activités déjà entreprises pour le lancement de $P C$-4, mais cette fois-ci, pour un différent groupe de centres de santé du secteur public à Lusaka. L'étude comprenait trois séries d'activités, à savoir: la formation des prestataires; la prestation des services de contraception d'urgence; et le rassemblement de statistique sur les services et d'autres données concernant les utilisatrices potentielles et réelles des services de contraception d'urgence. Par la suite, les résultats ont été comparés en tenant compte de ces deux groupes de centres de santé.

Malgré le fait que $P C-4$ avait été introduit il y a un an, les résultats de recherche sur les clientes des deux groupes ont révélé peu de différences quant à leurs connaissances et attitudes. Les deux groupes, par exemple, prétendaient tout aussi bien savoir comment éviter la grossesse suite aux rapports sexuels sans protection et en même temps incapables d'identifier une réponse correcte. Les clientes aux "cliniques Postinor-2" comme celles aux "cliniques $P C-4$ " avaient les mêmes chances, soit de reconnaître le nom "contraception d'urgence", soit d'être au courant que les pilules contraceptifs pourraient être pris en cas d'urgence. Vu ce manque de connaissance, l'étude recommande une dissémination plus systématique des informations relatives à la méthode.

Les taux d'approbation des deux produits ont suivi des trajectoires semblables. Après avoir graduellement commencé ; l'approbation des deux produits a atteint son maximum au bout de 4-6 mois environ, puis elle s'est stabilisée. Bien qu'on ait distribué plus de $P C$-4 que de Postinor-2, la disparité était fonction des différences dans la taille des deux zones de couverture, des soucis des prestataires sur la disponibilité à long terme de Postinor-2, et des préférences des prestataires pour $P C$-4 elle-même. Beaucoup de prestataires ont perçu Postinor-2 comme étant "plus expérimentale » que $P C$-4 et, contrairement à leurs clientes, la plupart des prestataires connaissaient bien déjà la contraception d'urgence et même la marque $P C$-4. Etant donné l'influence possible des préférences de ces prestataires, l'étude a recommandé, qu'en attendant que les autorités concernées en Zambie choisissent de reconnaitre un seul produit de contraception d' urgence, les efforts de l'IEC devraient rester neutres envers la marque et porter plus sur les possibilités d'éviter les grossesses non désirées que sur les attributs commerciaux d'une quelconque PCU. 
La deuxième question abordée dans cette étude était l'impact des niveaux réduits des effets secondaires de Postinor-2 sur le comportement des clientes et les services rendus à ces dernières. La plus grande préoccupation était qu'une méthode de contraception d'urgence "plus supportable" ne motive plus de femmes à adopter les méthodes usuelles de planification familiale. D'une façon générale, les résultats de cette étude indiquent un rapport faible entre les effets secondaires et l'adoption d'une méthode usuelle. Sans distinction de choix entre PC-4 et Postinor-2, la plupart des utilisatrices de contraception d'urgence ont éventuellement adopté une méthode de planification familiale usuelle. Quant à la transition aux méthodes anticonceptionnelles plus efficaces, les similarités parmi les groupes ont encore une fois dépassé les différences. Parmi toutes les femmes qui sont revenues pour leur visite de contrôle et qui ont choisi une méthode de planification familiale, l'adoption des méthodes très efficaces et essentiellement hormonales a atteint au moins 90 pour-cent. En dernier lieu, relativement aux attitudes des utilisatrices de la contraception d'urgence envers les méthodes elles-mêmes, les antécédents médicaux ont révélé peu de différences. Sur les 59 utilisatrices de Postinor-2 qui sont venues pour la visite de contrôle, il n'y a qu'une seule qui a dit qu'elle ne recommanderait pas cette méthode à une amie; la raison donnée étant l'échec de la méthode. Un pourcentage un peu plus élevé des anciennes utilisatrices de $P C$-4 ont affirmé qu'elles ne recommanderaient pas la méthode; mais dans les deux cas, l'approbation de la méthode a dépassé 95 pour-cent.

L'étude conclut en affirmant qu'au niveau de la prestation des services, les similitudes entre PC-4 et Postinor-2 obscurcissent les différences. Les utilisatrices de planification familiale montrent peu de préférences ou d'aversions pour les deux produits. Elles en adoptent à des taux comparables, et après les avoir employés, manifestent peu de différences dans leur appréciation des deux produits; en ce qui concerne leur décision d'adopter une méthode de planification familiale usuelle; ou même leur choix de méthode. Du point de vue du prestataire aussi, les similarités dépassent les différences.

Mais l'étude met également en lumière d'énormes différences importantes entre les deux produits, et certaines de ces différences pourraient avoir des conséquences sur la prestation des services. Une différence se rapporte par exemple aux provisions et à la logistique. L'un des atouts d'un régime de PCU combiné est qu'il peut être toujours remplacé par des contraceptifs combinés usuels. En cas d'épuisement de stocks ou d'un plan de réduction des coûts, $P C-4$ peut toujours être remplacé d'une manière moins coûteuse par les provisions disponibles. Postinor-2, par contre, n'a pas d'équivalent réel dans la gamme de méthodes disponibles dans les centres médicaux. Tout un cycle de mini pilules pourrait offrir le même niveau d'hormones contenues dans un seul cachet de Postinor-2, mais il n'est pas certain que les hormones qu'il contient ne soient transformées par le métabolisme de la même manière; ou que les femmes acceptent d'ingérer tout un cycle de pilules d'un seul coup. De plus, la substitution n'était pas rentable car le prix unitaire de Postinor-2 et celui d'un cycle de mini pilules est presque le même.

Cependant, parallèlement, la littérature disponible met également en relief certains inconvénients du régime combiné, notamment ses taux d'effets secondaires comparativement élevés et son efficacité moindre dans la prévention de la grossesse. Comme le démontre clairement la présente étude, aucun facteur pris isolement ne peut déterminer lequel des produits, PC-4 ou Postinor-2, représenterait le produit idéal pour la Zambie. Coût, efficacité, taux d'effets secondaires, flexibilité de distribution et probabilité d'obtention de bailleurs -- tous ces facteurs doivent, dans une certaine mesure, entrer dans l'équation. Ce que cette étude démontre en réalité, est que quelque soit le produit choisi, les agents de planification de la santé et les autorités réglementaires peuvent bénéficier de l'ensemble des informations rassemblées depuis l'introduction de $P C-4$ en matière de prestations de services. Il est vrai qu'il existe des réelles différences entre les deux produits, mais celles-ci ne nécessitent pas de nouveaux programmes de formation, des mécanismes différents de soutien pour les clientes ou même des stratégies distinctives pour la dissémination des informations. 


\section{TABLE OF CONTENTS}

ACKNOWLEDGEMENTS $\quad$ i

INTRODUCTION

BACKGROUND 2

De-medicalizing emergency contraception $\quad 2$

Reducing the side-effects of emergency contraception 4

OPERATIONS RESEARCH STUDY $\quad 6$

PROVIDER TRAINING $\quad 6$

DELIVERY OF EMERGENCY CONTRACEPTION SERVICES 6

DATA COLLECTION

$\begin{array}{ll}\text { Survey of MCH/FP clients } & 7\end{array}$

$\begin{array}{lr}\text { Client history forms } & 8\end{array}$

$\begin{array}{ll}\text { Provider interviews } & 8\end{array}$

IS THE ENVIRONMENT RIGHT FOR ANOTHER METHOD? $\quad 9$

RESEARCH FINDINGS $\quad 10$

CONCLUSIONS 13

DO FEWER SIDE EFFECTS MAKE A DIFFERENCE? 15

RESEARCH FINDINGS 15

$\begin{array}{ll}\text { Routine use of emergency contraception } & 16\end{array}$

$\begin{array}{ll}\text { The transition to more effective contraception } & 17\end{array}$

$\begin{array}{ll}\text { Preferences for emergency contraception products } & 18\end{array}$

$\begin{array}{lr}\text { CONCLUSIONS } & 18\end{array}$

FROM RESEARCH TO ACTION: THE NEXT STEPS 19

$\begin{array}{ll}\text { REFERENCES } & 22\end{array}$ 


\section{ACKNOWLEDGEMENTS}

The authors would like to express their gratitude to the many people whose support and collaboration made possible the activities and findings described in this report. We would especially like to thank Dr. Esther Muia of the Population Council/Nairobi and Dr. Peggy Chibuye of USAID/Zambia, both of whom faithfully "came to the rescue" whenever called, and in so doing made it possible to launch and implement this study in a timely and efficient manner. A special word of thanks is also due to Dr. Peter Fajans and Mr. Peter Hall of WHO/HRP whose help and perseverance led to the generous donation by Gedeon Richter, Ltd. of the contraceptive commodities required for this study. And lastly, credit must be given to five wizards whose unique skills made possible the analysis and presentation of this research. To these individuals: Ms. Moonga Simuyandi, Mr. Joseph Banda, and Mr. Clement Mwakamui of Lusaka's University Teaching Hospital; to Ms. Lucy Ng'ang'a of the Population Council/Nairobi; and to Ms. Pauline Zoundi of the Population Council/Ouagadougou, we offer our many thanks

One of the truly distinctive features of this study is the fact that it has been, ever since its inception, a highly participatory exercise. Most of the project's service delivery, training and even data collection components are managed by a steering committee whose membership is drawn from providers at each of the service delivery points involved in the project. The authors would like to convey their gratitude to these providers, but particularly those who joined us for the first time with this study:

Chelstone Health Centre : Susan Banda, Annie Mutanuka

George Health Centre: Dorothy Phiri, Patricia Kekelwa

Kabwata Health Centre: Rachel Siachobe, Idah Kapombwe

Kamwala Health Centre: Virginia Munamunungu, Stella Kumwenda

And finally, none of the activities described in this report would have been possible without the generous support of the project's funding agencies. For that support, we wish to thank the United States Agency for International Development, the World Health Organization's Special Programme of Research, Development and Research Training in Human Reproduction, the Canadian Public Health Association, and the British Department for International Development. 


\section{INTRODUCTION}

This report is the third in a series of summaries produced in connection with the operations research project, Enhancing Access to Family Planning Services through the Introduction of Emergency Contraception. Launched in September 1997, the project explored the broad range of issues surrounding the introduction and delivery of emergency contraception services in a developing country context. ${ }^{1}$ The first phase of the project, which concluded in March 1998, was an exploratory exercise, designed to identify strategies for overcoming difficulties associated with the introduction of emergency contraception. The second phase, of which this study is a part, uses operations research to test the problemsolving strategies identified in Phase One.

The study described in this report compared the introduction of two different emergency contraception pills: the combined oral contraceptive $P C-4$, first introduced into Zambia by this project in 1997, and the progestin-only contraceptive, Postinor-2, developed under the sponsorship of the International Consortium on Emergency Contraception. Implemented at four public sector clinics in Lusaka, Zambia, the study sought to identify whether there were any differences in the service delivery requirements associated with the provision of the two methods; in the range, frequency and/or severity of side effects associated with the use of the two methods; and in the consequences of such differences on client attitudes or behavior. Ultimately, the goal of this exercise was to provide an empirical basis for generalizing the lessons learned under Phase One of this project should circumstances require the registration and introduction of an emergency contraception product, other than PC-4.

This report follows the structure of the previous two research summaries (Ahmed et al 1998; Skibiak et al 1999). The first section recounts the events and circumstances that led to the development of this study; it details the interventions tested; and it describes the rationale underlying the selection of these particular interventions. The next section follows with a summary of the study's research methodology and principal data collection activities. The fourth and fifth chapters detail the research findings and outline their implications for future programmatic activities. Finally, the discussion concludes with a review of areas for subsequent action.

\footnotetext{
${ }^{1}$ Emergency contraception refers to methods women can use to prevent pregnancy following unprotected intercourse. There are several types of emergency contraception. The most widely used involves oral contraceptive pills taken within 72 hours of intercourse, followed by an additional number 12 hours later. The number of pills taken will vary, depending on their hormonal composition and dosage. One regimen, commonly referred to as "Yuzpe", involves the provision of two high-dose combined oral contraceptive tablets (each containing levonorgestrel, $250 \mu \mathrm{g}$ plus ethinyl estradiol, $50 \mu \mathrm{g}$ ) followed by a further two tablets 12 hours later. The product $P C-4$ is an example of the Yuzpe regimen packaged specifically for emergency contraception use. Another regimen involves the initial provision of one tablet containing $750 \mu \mathrm{g}$ levonorgestrel, followed by another tablet 12 hours later. This progestin-only formulation has been packaged and marketed under the brand name Postinor-2.
} 


\section{BACKGROUND}

A critical stage in the development of any strategy for contraceptive introduction is the identification of a product whose formulation, dosage, or even brand name can be deemed appropriate for the local environment.

In September 1997, the Population Council's Africa OR/TA II project launched an operations research study entitled Enhancing Access to Family Planning Services through the Introduction of Emergency Contraception. Implemented by Lusaka's University Teaching Hospital, the study introduced into Zambia for the first time a single dedicated product containing four high dose oral contraceptive tablets, each containing levonorgestrel, $250 \mu \mathrm{g}$ plus ethinyl estradiol, $50 \mu \mathrm{g}$. Manufactured under the brand name $P C-4$, this product is one of the world's leading emergency contraception methods. It is registered in over eight countries, including the United Kingdom, Switzerland, Germany, and South Africa.

By any standards, the introduction of $P C-4$ in Zambia has been an unmitigated success. Through the involvement of four major providers of reproductive health services (University Teaching Hospital, the Ministry of Health/Central Board of Health, the Planned Parenthood Association of Zambia, and the University of Zambia) emergency contraception is now available at more than 21 health care facilities across Lusaka and the rural Copperbelt. Since September 1997, over 1,500 packets have been dispensed through the project.

Though client history records indicate that the efficacy, side effects and client perceptions of PC-4 are very much in line with the existing literature, a review (Ahmed et al. 1998) of the study's Phase One findings recommended exploring the acceptability of another widely-used emergency contraceptive product, Postinor-2, manufactured by Gedeon Richter, Ltd. Currently in use by the International Consortium on Emergency Contraception, Postinor-2 is a progestin-only formulation, consisting of only two tablets, each containing levonorgestrel, $750 \mu \mathrm{g}$.

De-medicalizing emergency contraception: The recommendation to introduce Postinor-2 reflected two broad concerns to emerge from Phase One of the study. The first was the opportunity it offered to expand the number and range of outlets through which emergency contraception services could be made available. A key finding of the Phase One review was that traditional clinic-based facilities were failing to reach many of those most in need of emergency contraception. This included both in- and out-of-school youth as well as the majority of women who regularly engage in unprotected intercourse, yet do not feel at risk of becoming pregnant (Ahmed et al., 1998: 13). To reach these populations, the review called for greater de-medicalization of emergency contraception services and, more specifically, for a diversification of the kinds of outlets through which it might be provided. These outlets might include, for example, community-based distributors, pharmacies or even peer counselors. 
Though the call for demedicalization was supported by a broad cross-section of Zambia's reproductive health community ${ }^{2}$, one potential obstacle facing such a move was the longstanding resistance of $P C$-4's manufacturer, Schering AG, to over-the-counter sales of its products, or to local registration efforts that failed to guarantee strict medical supervision of product distribution. (Ellis 1998, Consortium for Emergency Contraception 1996: 9). Obviously, this stance presented the project - and indeed the health care community as a whole - with a potential predicament. What if, for example, research were to suggest that non-clinical distribution of emergency contraception pills held the greatest potential for reaching under-served populations? Zambia might very well find itself in the position of either: 1) being refused Schering's support to register $P C$-4; or 2) being provided support for registration only under the condition that it accept distribution arrangements that would effectively place the product beyond reach of those whose unmet need for emergency contraception was greatest.

Figure 1

POSTINOR-2 and PC-4

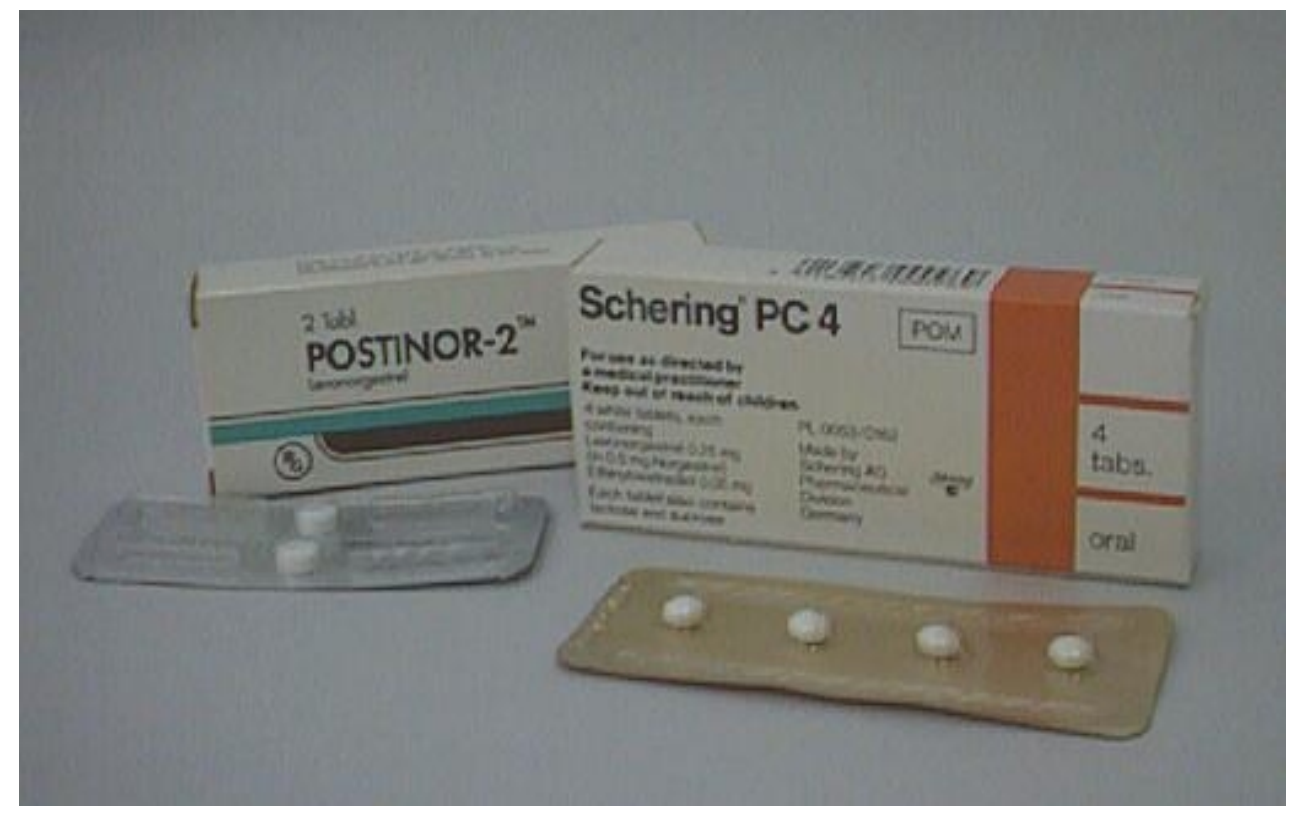

The decision to introduce an alternative contraceptive product, therefore, was seen as the most effective means to expand the contraceptive options available for review by Zambia's chief regulatory agency, the Drug and Poisons Board. By demonstrating the acceptability or even comparability - of an alternative emergency contraception product, it was hoped that the future role of emergency contraception in Zambia would be better able to reflect the reproductive health needs of Zambia's women.

\footnotetext{
2 On 10 March 1998, a national workshop was held to disseminate the findings of Phase One of the present operations research study. Attended by more than 80 participants representing the service delivery, academic, and $\mathrm{NGO/international} \mathrm{donor} \mathrm{communities,} \mathrm{it} \mathrm{was} \mathrm{from} \mathrm{this} \mathrm{workshop} \mathrm{that} \mathrm{the} \mathrm{recommendation} \mathrm{emerged} \mathrm{to} \mathrm{expand} \mathrm{the}$ range of potential emergency contraception providers. For a more detailed account of the workshop proceedings, see Ahmed et al (1998).
} 
The choice of Postinor-2 as the alternative option was a logical one insofar as the product itself was the result of a collaborative agreement between its manufacturer, Gedeon Richter, and the International Consortium on Emergency Contraception. At the latter's request, Gedeon Richter repackaged its popular $750 \mu \mathrm{g}$ levonorgestrel tablets, previously marketed under the brand name "Postinor", into two-tablet packages suitable for one-time emergency contraception use. Up until that point, Postinor had been registered in 29 countries, including Kenya, Zimbabwe, Nigeria, all of Eastern and Central Europe and the former Soviet Union (Camp 1998: 225). In 1997, the new "Postinor-2", became the sole emergency contraception product for use in all research and service delivery trials carried out under the auspices of the International Consortium.

Reducing the side-effects of emergency contraception: In addition to broadening the range of contraceptive options, there was another reason for exploring the acceptability of Postinor2. It was the increasing body of evidence suggesting that it might actually offer certain advantages over the combined Yuzpe regimen, of which $P C-4$ is an example.

Though the range and severity of side effects associated with $P C$ - 4 in this study were in line with those reported elsewhere in the literature, overall, providers still felt their incidence was high: over 80 percent of the women who received emergency contraception through this study experienced at least some side effect. Levels of nausea were particularly high, even exceeding those reported by Ho and Kwan in their 1993 study comparing levonorgestrel with the Yuzpe regimen (see Figure 2).

Figure 2

Frequency of Side Effects Associated with Use of Yuzpe Regimen

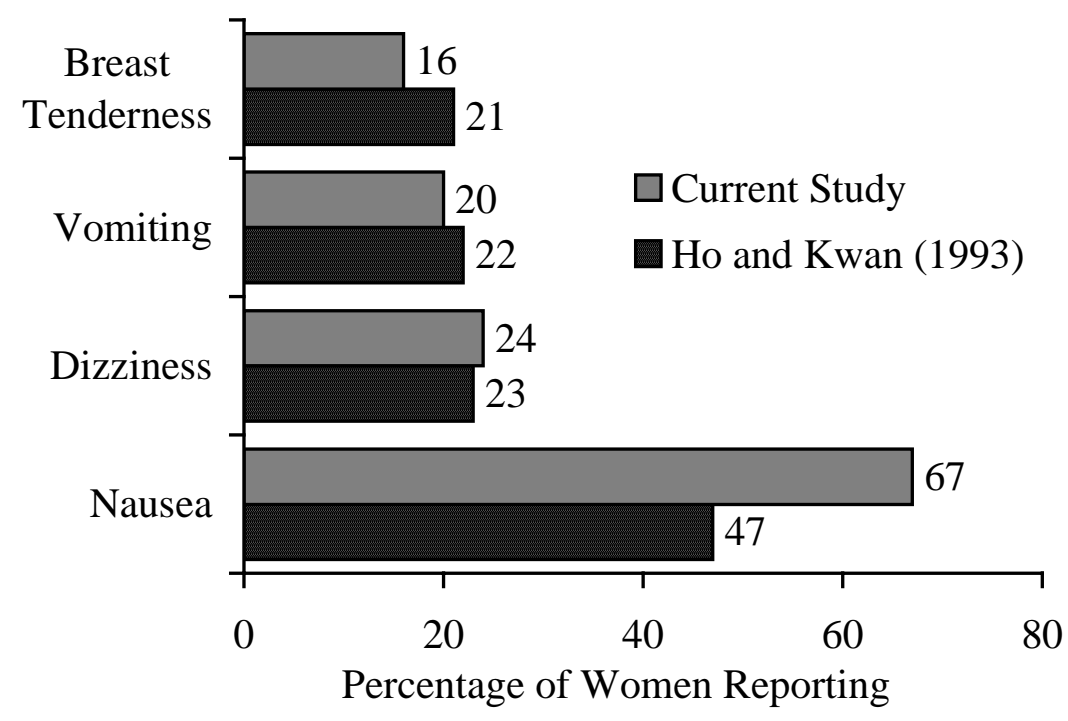

In reviewing the findings of Phase One, a number of reasons were suggested as to why the level of side effects under this study could have varied from those reported in Ho and Kwan. One explanation was simply a discrepancy over definitions: women who might otherwise have reported mild vomiting (which, incidentally, occurred less frequently than in Ho and Kwan's study), for example, could have described their symptoms as nausea. Another was 
differences in the quality of counseling, particularly with respect to the importance of taking emergency contraception with food as a means to reduce nausea (Hatcher et al 1994: 443). A third explanation, however, was the product itself. In Ho and Kwan's (1993) study, for example, nausea associated with the use of a progestin-only emergency contraception pill (such as Postinor-2) was reduced by as much as 65 percent, vomiting by 88 percent, dizziness by 20 percent and breast tenderness by 24 percent.

Because previous clinical trials had already compared and documented the technical efficacy of different emergency contraception formulations, there was little point in doing so again if the only outcome were to be similar sets of technical data. Instead, what the present study sought to do was to explore the impact of these technical differences on client attitudes and assess the implications of such differences for the service delivery system. Ultimately, it was hoped that the results of this research would make it possible to determine whether the lessons learned to date in connection with $P C-4$ could, in fact, be generalized in the event it became necessary to explore the registration and introduction of an alternative emergency contraception product. In that sense, therefore, the objectives of this project were really quite modest. Ultimately, they sought to show that the consequences of delivering Postinor-2, if not better, would at least be comparable to those associated with the delivery of $P C-4$. 


\section{Operations RESEARCH STUDY}

Launched in April 1998, the ultimate objective of this study was to accumulate enough firsthand experience with the delivery of Postinor-2 to be able to answer the following questions:

- Are there any significant differences in the service delivery requirements associated with the provision of Postinor-2 as opposed to $P C-4$ ?

- Are there any significant differences in the range, frequency and/or severity of side effects associated with the use of Postinor-2 as opposed to PC-4? Should such differences exist, do they influence client attitudes or behavior?

The design of the study entailed a replication of activities previously undertaken to introduce $P C-4$, but among a different group of public sector clinics. Three major sets of activities were carried out: provider training; the delivery of emergency contraception services; and the collection of service statistics and other data on potential and actual users of emergency contraception services. Results were then compared across the two groups of health care facilities.

\section{Provider Training}

From 26-29 June 1998, eight health care providers from four Lusaka-based health facilities (Chelstone, Kabwata, Kamwala and George clinics) were trained in emergency contraception. Because of a 1997 directive by the Zambia Central Board of Health banning all off-site training workshops, training was carried out on-site at each participating health care center. Training lasted one day and utilized the same materials adopted during Phase One of the operations research study. The materials were drawn from the packet published by the Consortium for Emergency Contraception. Each participant was also provided with a complete set of materials for use during the training and to keep as a permanent reference source. Finally, a locally produced pre- and post-test instrument was used to evaluate technical knowledge.

\section{DELIVERY OF EMERGENCY CONTRACEPTION SERVICES}

A fundamental premise of WHO's Strategy for Contraceptive Introduction and Technology Transfer is that any new method must be provided within the context of a broad contraceptive choice so that the focus of the introductory effort is not on one single method, but on the strengthened delivery of all methods (Simmons et al 1997: 79-94). From the very outset, the study has adhered closely to this philosophy by training and equipping only those providers and health facilities capable of offering their clients a full range of reversible and permanent methods. With these criteria in mind, the four public sector clinics selected to participate in this study ${ }^{3}$ all had MCH/FP staff trained to provide general family planning services and were

3 All of these health centers offer their clients a full range of reversible methods. Permanent methods and 
comparable in terms of client characteristics, staffing, and infrastructure to the four clinics involved in Phase One (see Figure 3).

In June 1998, all four centers began providing Postinor-2 to clients who requested treatment for unprotected intercourse, method failure, or rape. After receiving emergency contraception services, the women were asked if they would be willing to participate in the present study. They were given a brief description of the aims of the project; they were told that all information collected from them would be stored securely; and they were assured that the written results of research findings would not include any details that could identify them.

Figure 3

Geographic Distribution of Health Center Catchment Areas

Receiving PC-4 and Postinor-2

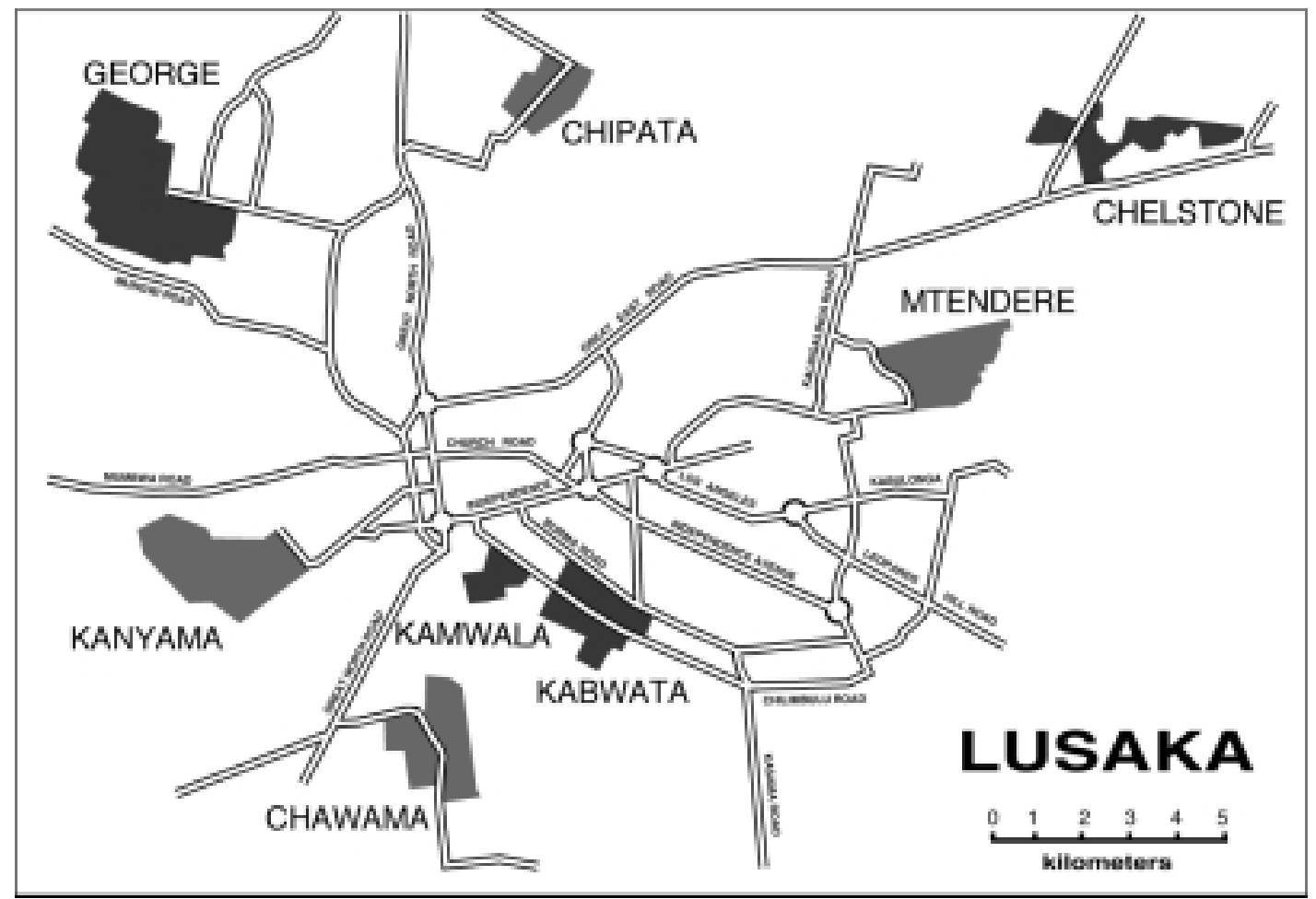

All supplies of Postinor-2 used in this project were made possible through the support of the International Consortium on Emergency Contraception, WHO's Special Programme of Research, Development and Research Training in Human Reproduction, and Gedeon Richter, Ltd.

\section{Data Collection}

Three major data collection activities took place during this study. They included:

longer-term methods such as Norplant ${ }^{\circledR}$ and the IUD are also available, either on-site or through referral. 
SuRvey OF MCH/FP CliENTS: From 28 May to 8 September, 1998, a survey of knowledge, attitudes and practices (KAP) towards emergency contraception was administered to 1,600 women attending MCH/FP services at the four public sector health centers involved in this phase of the study. The survey instrument and data collection/analysis procedures were identical to the those used six months earlier in a KAP survey of 1,600 MCH/FP clients at the clinics involved in Phase One of the study. The objective of the survey was threefold. First, it was carried out in order to establish the comparability of the client population involved in Phase One of the study with those attending the four clinics involved in this intervention.

The second reason for implementing the survey was to ensure that the interventions undertaken during this phase mirrored those carried out previously. In Phase One, for example, it was found the survey had had a notable effect on communicating information about emergency contraception to both $\mathrm{MCH} / \mathrm{FP}$ clients and the community at large. There were even indications that the questionnaire provided a "trigger" or "on-the-spot" source of information for women who, though unaware of its existence beforehand, were in a position to have actually benefited from it. To ensure that recipients of Postinor-2 received the same information as that provided to users of $P C-4$, the survey was repeated using the same instrument and data collection/analysis procedures.

Finally, for data collection purposes, the survey proved to be a useful research tool for obtaining insight into women's awareness, beliefs, and sources of information about strategies used to prevent unwanted pregnancy. During the survey, clients were given a description of emergency contraception and then asked to indicate their impressions of it, whether they might ever use it, what they found most intriguing about it, and the range of persons they felt they could turn to for information on it.

CLIENT HISTORY FORMS: Client history forms were opened for all participants who received Postinor-2 though this study. Identical to those used by $P C-4$ recipients during Phase One, the forms consisted of three parts. The first examined the circumstances surrounding the act of unprotected intercourse that prompted the client to request emergency contraception. The second part, which is completed during the initial follow-up visit, sought information on such factors as side effects, effectiveness, and general attitudes towards the emergency contraceptive pill used. The third section recorded whether the client chose to adopt a routine family planning method, what that method was, and the circumstances surrounding that decision.

All client history forms were kept at the service delivery point for a period of two months or until the client returned for follow-up. Any client not returning after two months was considered lost to follow-up. Forms were then turned over to the project for continuous data entry.

Provider InTerviews: At the conclusion of this study, interviews were carried out among the providers at each of the participating health care facilities. The interviews sought to gauge provider knowledge and attitudes towards emergency contraception and discern service delivery patterns that might be attributed to provider attitudes and biases. During the interviews, providers were asked to reflect upon overall use patterns of emergency contraception at their clinic; the circumstances under which they would and would not recommend emergency contraception; and what they saw its shortfalls to be. 


\section{IS THE ENVIRONMENT RIGHT FOR ANOTHER METHOD?}

In August 1997, the emergency contraception pill, $P C-4$, was introduced into 21 health care facilities across Lusaka and the rural Copperbelt. Among these facilities were Lusaka's University Teaching Hospital, fifteen health centers within the Central Board of Health, four clinics operated by the Planned Parenthood Association of Zambia, and the main campus clinic of the University of Zambia. To date over 1,500 women have received $P C-4$ through this study. Many thousands more have been informed about it as the only means available to prevent unwanted pregnancies after unprotected intercourse.

Although no effort was made to publicize the availability of emergency contraception beyond the original 21 clinics, distribution of $P C-4$ has clearly increased over the last 18 months. The method has even established itself within the marketplace, with reports of pharmacies and drug venders charging up to 10,000 Kwacha per packet (approximately US\$4.25) - nearly 20 times the price of the leading socially marketed brand of oral contraceptives. Even at the health center level, distribution of $P C-4$ has expanded beyond the sites originally affiliated with this project. Accounts of $P C$-4 usage have been reported as far away as Livingstone and Kabwe.

In addition to greater utilization of $P C-4$, knowledge about the product has particularly expanded among health care providers. Prior to the introduction of the method, 89 providers were trained in emergency contraception at three separate one-day workshops. All of these individuals returned to their respective health centers where many, through routine procurement channels, obtained $P C$ - 4 and began providing it to their clients.

It was, therefore, against this backdrop of broad product dissemination, extensive provider training and increasing brand recognition that the decision was made to introduce Postinor-2 into four public sector health care facilities distributed across Lusaka. One of the most immediate issues to be addressed by the study, therefore, was to determine whether such preexposure to $\mathrm{PC}-4$ would influence the acceptability or adoption of a new emergency contraception product. Obviously, the answer to this question would have a direct bearing on the supposed "comparability" of the two products, since existing attitudes, positive or negative, could easily have undermined the introduction and/or acceptability of Postinor-2 at the outset.

The first issue to be addressed by the study, therefore, focussed specifically on factors associated more with the public image or knowledge of emergency contraception, than with the behavioral consequences of actually having used an emergency contraception product itself. Were the clients of the four health centers, for example, truly comparable to those at the centers where $P C-4$ had been originally introduced? Did the interventions, training and dissemination activities that took place during the first year of this project really influence knowledge or attitudes about emergency contraception, or about $P C-4$ specifically? And thirdly, did acceptance rates of the two products follow a similar trajectory? Was one more readily accepted than the other, or did they both follow comparable distribution levels? 


\section{Research findings:}

To assess the comparability of factors likely to influence product acceptability, a survey of knowledge, attitudes and practices (KAP) towards emergency contraception was administered to 1,600 women attending MCH/FP services at the four "Postinor-2 clinics" involved in this phase of the study. As noted previously, the survey instrument was identical to the one applied 6-12 months earlier at five of the 21 facilities involved in Phase One of the study where $P C-4$ was administered.

Overall, the survey results revealed striking similarities in the client populations of the two groups of clinics. Though age distribution varied slightly from clinic to clinic, between groups, the pattern was virtually identical (see Figure 4)

Figure 4

Age Distribution of $\mathrm{MCH} / \mathrm{FP}$ Clients

at $P C-4$ and Postinor-2 Clinics

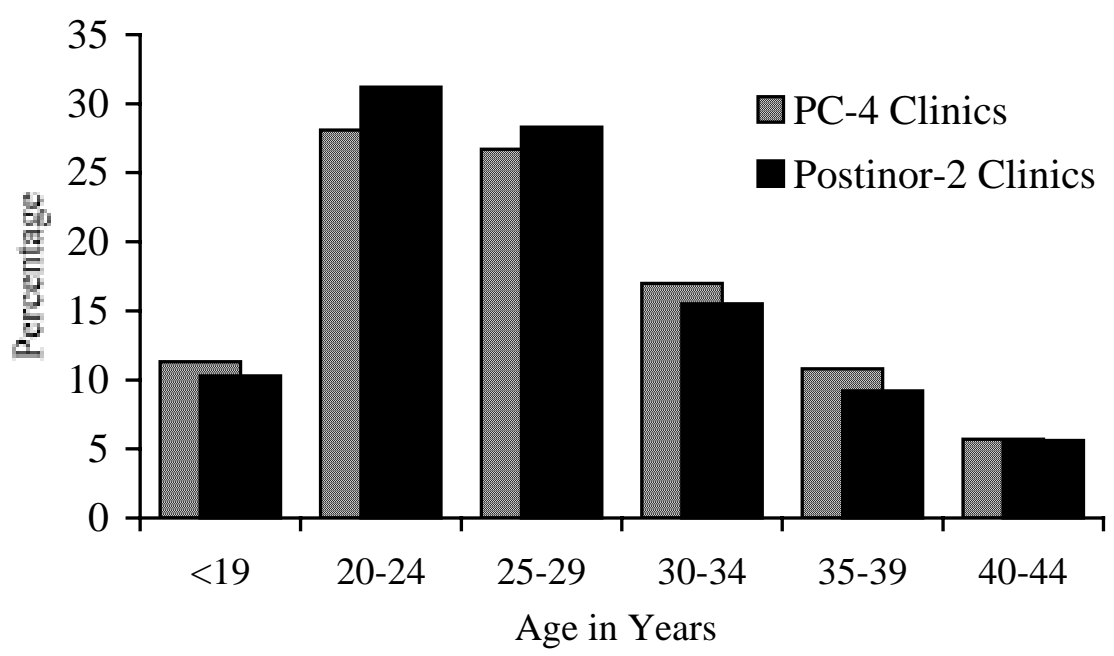

Educational levels of the two groups were also virtually identical, with roughly 40 percent of all clients having completed primary school, 40 percent having completed secondary school and the remainder divided evenly between those who had attended, but not necessarily completed university or primary school.

A third potential determinant of emergency contraception use, contraceptive prevalence, also proved to be strikingly similar, with 75 percent of clients $(\mathrm{N}=1,176)$ at the $P C-4$ clinics claiming to be current users of a family planning method, versus 69 percent $(\mathrm{N}=1,107)$ at the Postinor-2 clinics. Even the distribution of the methods was virtually alike, with pills and injectables making up 84 and 87 percent, respectively, of the method mix; while condoms accounted for no more than 5 percent of all users in either group (see Figure 5).

Ultimately, however, the principal objective of these comparisons was to gauge whether preexposure to $P C-4$ - or even to the concept of emergency contraception, itself - stood to influence client acceptability of a new method such as Postinor-2. 
Figure 5

Method Mix of Family Planning Users at MCH/FP Facilities

of $P C-4$ and Postinor-2 Clinics

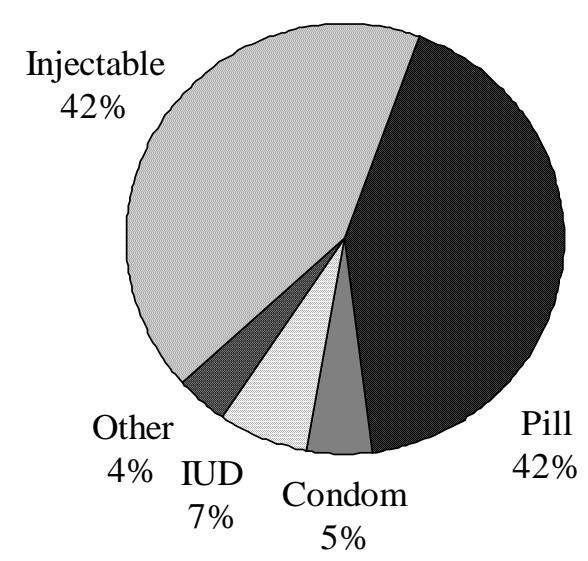

$P C-4$ Clinics

$\mathrm{N}=1,176$

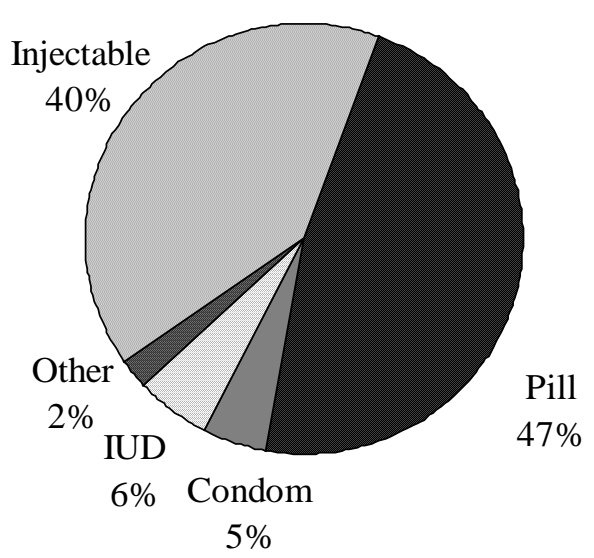

Postinor-2 Clinics

$\mathrm{N}=1,107$

In several respects, the results of the KAP survey proved quite surprising. For one thing, they show that despite the "backdrop of broad product dissemination", there were no notable differences in knowledge and attitudes towards emergency contraception between the Postinor2 clinics and the $P C-4$ clinics. Both groups, for example, were equally likely to claim they knew ways of preventing pregnancy after unprotected intercourse (38.9 and 36.8 percent, respectively). Furthermore, as shown in Figure 6, their delineation of different solutions was virtually identical. In both cases, traditional remedies such as the ingestion of nonprescription drugs (especially iron tablets or chloroquine); the drinking of various herbal infusions, or the insertion into the vagina of foreign objects were cited most often. This was followed by some (usually incorrect) regimen of pill use, and then by the identification of emergency contraception by name. Indeed, clients at the Postinor-2 clinics were no more likely than those at the $P C$-4 clinics, either to recognize the name "emergency contraception", or to be aware that oral contraceptives could be used for emergency purposes. Furthermore, in both surveys, the primary source of information about emergency contraception (at least for those who knew about it) was the clinic itself, followed by friends.

What these findings suggest, therefore, is that despite the higher mobility and greater social complexity of urban populations, the catchment areas of the different health centers may be much more circumscribed than is typically assumed. At one level, this finding speaks directly to the need for more broad-based IEC strategies on emergency contraception. At another, however, it suggests that - at least at this stage - knowledge of emergency contraception is still limited enough to ensure that a larger scale introduction of Postinor-2 would not likely be encumbered by preconceptions concerning either $P C-4$, or emergency contraception in general. 
Figure 6

Solutions Identified by MCH/FP Clients

for Preventing Pregnancy after Unprotected intercourse

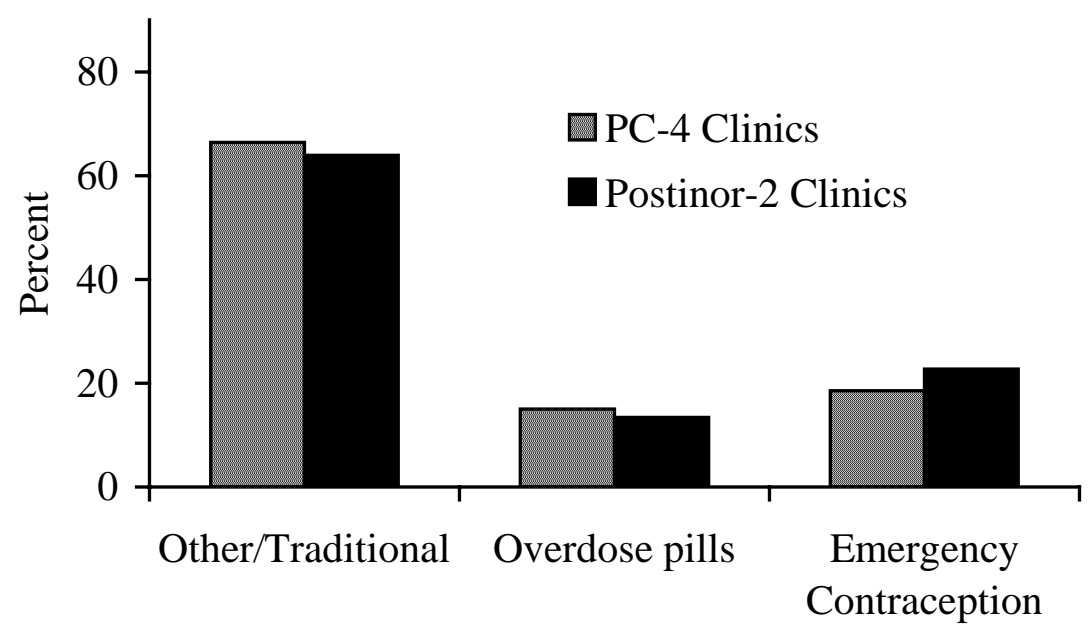

Perhaps it is for that reason that when one compares the actual acceptance rates of the two products over the first eight months of their availability, both followed a similar trajectory (see Figure 7). Acceptance of both began gradually, peaked at around 4-6 months, and then leveled off as clients better understood the role and effectiveness of emergency contraception in general. As was discovered during Phase One of the project, providers claimed that the initial surge in demand for emergency contraception was partially attributable to erroneous beliefs among some clients that it might also work an abortifacient (Ahmed et al 1998: 5). The decline in utilization, they argued, was the gradual result of continued IEC efforts and simply the personal experience of those who had used it unsuccessfully.

Although the distribution of $P C-4$ clearly exceeded that of Postinor-2 in absolute terms, the difference appears to have had little to do with prior client exposure to $P C-4$. For one thing, the sizes of the two catchment areas were quite different. The catchment population of the facilities offering $P C$-4, for example, was over 20 percent larger than that of the centers offering Postinor-2. In addition, $P C-4$ was made available through the national IPPF affiliate, PPAZ, at three of its health care facilities. The level of the each center's family planning activities also differed. Kanyama Clinic (in the $P C-4$ group), for example, averaged over 30 new family planning acceptors per month, compared to the monthly averages at the George and Chelstone clinics which barely exceeded 2.

Another factor that may have contributed to a lower distribution of Postinor-2, were provider concerns over the long-term availability of the product. In the case of $P C-4$, at least 50,000 units of the product had been purchased two years earlier by the British Overseas Development Administration. Although 2,000 packets of Postinor-2 had been ordered for the present study, initial delays made it necessary to begin project activities with a minimal supply of only 50. The fact that each health center was issued an initial allotment of only 10 packets (with 10 held in reserve by the project) clearly gave rise to doubts among providers 
over the adequacy of existing stocks. Consequently, until the full stock of commodities arrived in August, 1998, some providers admitted having first "used up" their existing stocks of $P C-4$, before distributing Postinor-2. Only in August (month 3 of the study) were all remaining $P C-4$ packages removed from the four participating clinics.

Figure 7

Quantities of PC-4 and Postinor-2 Distributed per Month

At Participating Health Care Centers

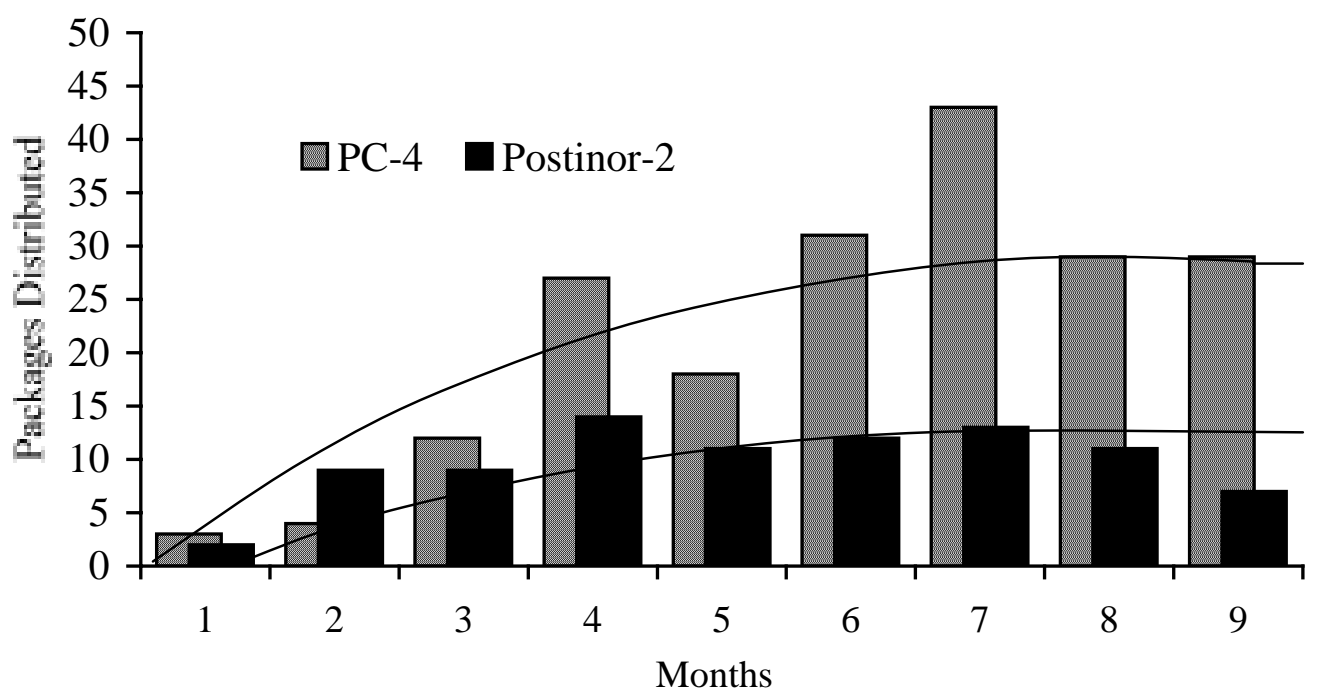

Finally, a third factor that may have contributed to the comparatively lower distribution of Postinor-2, was the perception among some providers that Postinor-2 was somehow more "experimental" than the better known and more widely used $P C$-4. In interviews, providers often claimed that $P C$-4 had already become so synonymous with emergency contraception, that clients were requesting it by name. While there is no reason to doubt that such requests did occur from time to time, it is unlikely such requests could have ever been considered routine, particularly since the results of the KAP survey questionnaire gave no indication that knowledge of emergency contraception, let alone $P C-4$, was that widespread.

In short, if brand preferences had indeed exerted any influence over the distribution curve, in all likelihood it was the preferences of providers. Many providers had, after all, already been trained to provide $P C$-4. And although every effort was made to dismiss any suggestion that Postinor-2 was experimental, no efforts were made to present it as a better product either.

\section{Conclusions:}

Despite apparent increases in the provision of emergency contraception pills, it is clear that public awareness of the method has remained limited to the catchment areas in which it currently being distributed ${ }^{4}$. To many in this study, such findings may be come as a

\footnotetext{
${ }^{4} \mathrm{KAP}$ studies carried out among MCH/FP clients at both the $P C-4$ and Postinor-2 show a consistent increase over time in the number of respondents who correctly identify emergency contraception as a means of avoiding
} 
disappointment - particularly given the intensity of project interventions; the number of health care providers trained in the method; and the fact that $P C-4$ is now in stock at more than 21 health care facilities across Lusaka and the rural Copperbelt.

But the irony of this discovery, is that it captures perhaps better than any other observation, both the challenges and opportunities that lay ahead in the effort to enhance access to emergency contraception services. On the one hand, it clearly points to the need for a more systematic attempt at disseminating information on emergency contraception - one that does not rest exclusively on direct provider-client interaction or less-formal channels of communication. Word of mouth can indeed be an extremely effective medium for communicating information, but for such information to spread beyond the catchment areas themselves, or to reach populations that do not routinely attend the health facilities (ie. youth, unmarried women), a wider, more systematic IEC effort will be required. ${ }^{5}$

On the other hand, however, these results also show that even if general information about emergency contraception has not spread widely, provider preferences can exert a powerful force on method selection. Providers were, for example, the ones most familiar with $P C-4$ and that familiarity clearly manifested itself in the frequency with which they distributed both it and Postinor-2.

What this suggests, therefore, is that until Zambian regulatory authorities select an emergency contraception product for regulatory approval, IEC efforts should probably remain brandneutral and focus more on the possibilities of preventing unwanted pregnancies in general, than on the technical or commercial attributes of any particular emergency contraception pill. Enough examples exist of both approaches to provide guidance to health care planners and providers in Zambia. ${ }^{6}$

pregnancy after unprotected sexual intercourse (see Ahmed et al 1998: 12).

5 The Phase One results, for example, showed that within the catchment areas of each health center, knowledge of emergency contraception spread quite rapidly.

6 In the United States and United Kingdom, IEC campaigns on emergency contraception have typically adopted a more indirect approach towards information dissemination, focussing primarily on the service options available to women in the event of unprotected intercourse. Often, these messages provide emergency phone numbers or the locations where services can be obtained. Obviously, one advantage of such a neutral approach, is that leaves open (though primarily to the provider) the specific type or brand of emergency contraception to be used.

In the developing world, by contrast, IEC has focussed very much on brand recognition. In Kenya, for example, the International Consortium on Emergency Contraception has produced posters and pocket calendars emblazoned with photos of the product used there, Postinor-2. In South Africa, a somewhat similar approach has been adopted in for Schering's " $E-G E N-C$ ", the local brand name for $P C-4$. One advantage of focussing on the brand-name is that it shifts responsibility for product identification to the client - an appropriate strategy in settings where providers might not be familiar with emergency contraception. 


\section{Do FewER SiDE EFFECTS MAKE A DIFFERENCE?}

All hormonally-based emergency contraception regimens entail some side effects. Those associated with the $P C-4$, for example, include the same range of effects commonly experienced with short-term use of combined oral contraceptives, though with higher frequency.

In Zambia, experience with the delivery of $P C$-4 suggested that both the range and frequency of side effects were very much in line with those reported in the literature. Indeed, except in the case of nausea, the frequencies of vomiting, breast tenderness and dizziness were actually lower than the figures cited in Ho and Kwan (1993). But however "in line" they may have been technically speaking, for many providers involved in this study, they were still too high: over 80 percent of all women who received $P C-4$, for example, experiencing at least some effect.

For at least a decade, research has shown that the frequency of side effects associated with progestin-only regimens of emergency contraception is significantly less than those associated with the use of combined oral contraceptives. Ho and Kwan, for example, argued that progestin-only emergency contraception pills (such as Postinor-2) could reduce the nausea associated with the Yuzpe regimen by as much as 65 percent, vomiting by 88 percent, dizziness by 20 percent and breast tenderness by 24 percent. Earlier studies by Glasier (1992) and Webb (1992) showed even greater reductions in the frequency of nausea and vomiting.

Although the present study also expected to observe these lower frequencies within Zambia, its primary goal was to understand what these reductions might mean for the service delivery system as well as for client attitudes and behavior. Would a reduction in the frequency of side effects, for example, impact on frequencies of return to follow-up; or on the subsequent adoption of a regular family planning method; or even on client/provider preferences between brands? In other words, did the use of Postinor-2 lead to a reduction in side effects associated with the use of emergency contraception, and if so what difference did that reduction make?

\section{Research Findings:}

In this study, the primary source of data on the follow-up and management of secondary effects were client records opened on all emergency contraception users. As noted previously, the client history consisted of three parts. The first examined the circumstances surrounding the act of unprotected intercourse that led to the request for emergency contraception. The second sought information on such factors as side effects, effectiveness, and general attitudes towards the emergency contraception product used; while the third

\footnotetext{
7 In addition to reducing levels of nausea and vomiting, there is solid evidence to suggest that a levonorgestrelonly regimen of emergency contraception may actually be more effective at preventing pregnancy (Task Force 1998: 428-433; Von Hertzen 1998: 222-232; Von Hertzen et al 1998: 1939). For further information on this issue, see page 21 , below).
} 
recorded whether the client chose to adopt a routine family planning method, what that method was, and the circumstances surrounding that decision.

Based on the results of 268 client history forms completed by the end of February 1999, the use of Postinor-2 did indeed reduce dramatically the level of side-effects associated with $P C$ 4 during Phase One of the study ${ }^{8}$. As shown below in Figure 8, it accomplished this by halving levels of nausea, virtually eliminating vomiting altogether, and as Ho and Kwan predicted, by reducing breast tenderness and dizziness.

Figure 8

Comparison of Side Effects

Associated With Use of Postinor-2 and PC-4

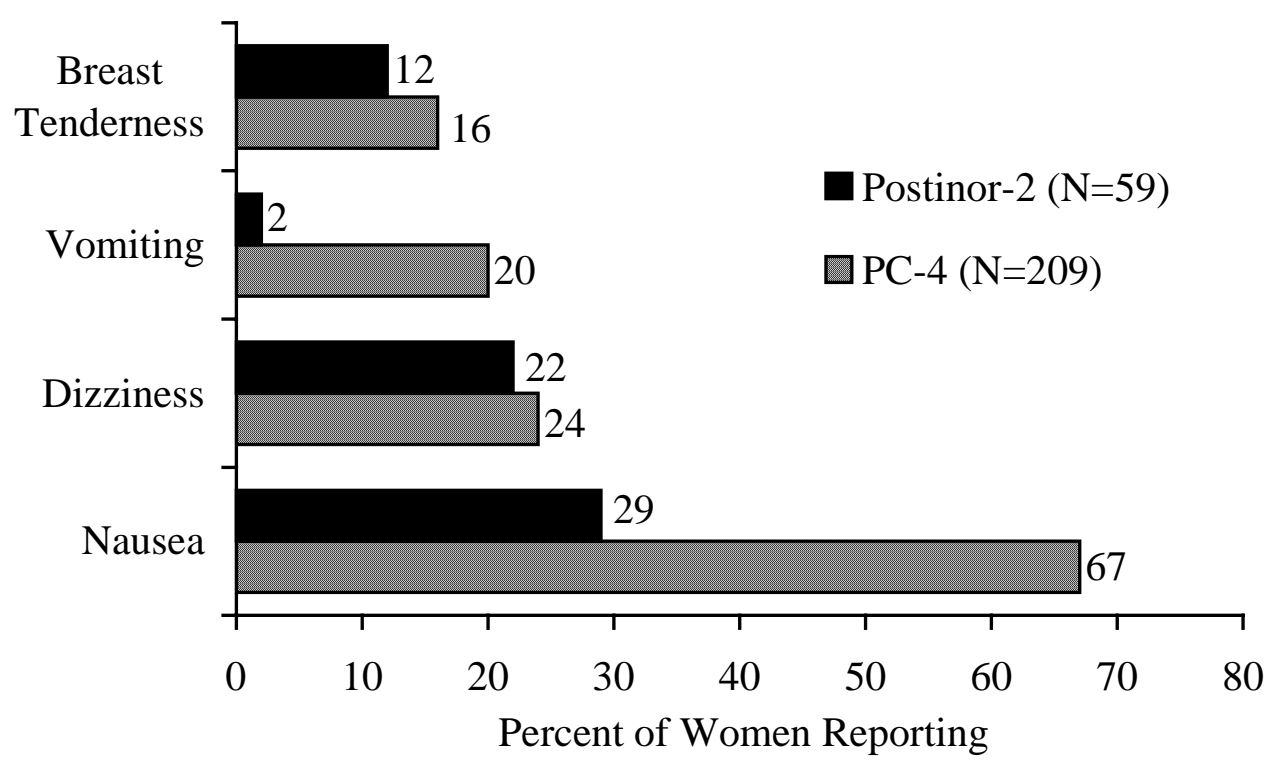

But did these declines in the frequency of side effects lead to any commensurate differences in either client behavior or in provider attitudes towards the new method?

Routine use of emergency contraception: While there is still much debate over the causal nature of linkages between enhanced access and repeat use of emergency contraception (Glasier et al 1998; Skibiak et al 1999), one of the strongest arguments against habitual use of emergency contraception is that the side effects alone would probably discourage most women from using it routinely. Indeed, avoidance of side effects was singled out during Phase One of this study as one of the more likely explanations for the dramatic shift among former emergency contraception users towards more effective, hormonal methods (Ahmed et al. 1998: 27-29).

8 Completed client histories refer to those client cases in which health care staff have completed all three sections of the client history form. Completed client histories would exclude both emergency contraception users lost to follow-up (failed to return within two months of initial visit) and those who had still not returned. The 209 completed $P C$-4 histories were collected over the 15 month period from November 1997 to February 1999. The 59 Postinor-2 histories were collected over the 9 month period from June 1998 to February 1999. 
Given this "positive side" to the otherwise negative effects of emergency contraception, concerns have occasionally been raised as to whether a "more tolerable" emergency contraceptive method might not, in effect, remove any incentive for women to shift to routine family planning methods. Though this argument fails to address the broader ethical issues surrounding choice, putting such issues aside for the moment, the question remains "is there any basis for such an argument?

Judging from the results of this study, the evidence for a relationship between side effects and the adoption of routine family planning remains weak. But even the information that does exist suggests that the relationship reflects far more than side effects alone. Just as important is the client's previous exposure to routine contraception and, related to that, whether or not the client ever returned to the heath center for subsequent counseling.

At the outset, it is important to emphasize that whatever impact side effects may have had on the continued use or subsequent adoption of routine family planning methods, the overwhelming majority of emergency contraception users eventually adopted a routine family planning method, regardless of whether they used $P C-4$ or Postinor-2. Among regular family planning users, for example, over 71 percent either continued with their method or chose another. Among non-users of a family planning method, the transition to routine contraception averaged 65 percent.

The differences that do emerge from the present study, seem to vary with, on the one hand, the type of emergency contraception method used and, on the other, whether the client was a regular family planning user. Among those reporting no prior use of contraceptives, for example, the differences between $P C-4$ and Postinor-2 users were practically non-existent. Both were equally likely to return to the health facility for their recommended "follow-up visit"; and both were equally likely to accept more effective (typically hormonal) family planning methods. But among regular family planning users, the reactions to $P C-4$ and Postinor-2 were somewhat different. The PC-4 users, for example, were less likely than Postinor-2 users to skip their follow-up visit and less likely to leave without having accepted a family planning method.

Why these divergences should exist is not entirely clear. One hypothesis may be that anyone unaccustomed to a hormonal method (or even those accustomed to them, but with fewer side effects than $P C-4$ ), is more likely to seek medical advice following emergency contraception because they are more likely to experience side effects with which they are unfamiliar. Those family planning users who received Postinor-2, by contrast, would not only have already been familiar with hormonal methods but less likely to encounter anything unfamiliar, given the fewer side effects of Postinor-2 in general.

The transition to more effective contraception: With respect to the transition from less to more effective contraceptive methods, once again the similarities across groups far outweigh any differences between them. Among all women who returned for their follow-up visit and chose a family planning method, the adoption of highly effective, essentially hormonal methods, reached levels of 90 percent and above. While this transition might be welcomed at some levels, one major concern expressed by Ahmed et al (1998: 28-29) is that it is taking place at the expense of barrier methods. Obviously, in areas of high STI prevalence, any reduction in condom use must be examined carefully to ensure that the trend does not continue. In the present case, the problem is a general one among emergency contraception 
users as a whole. Regardless of whether the product is PC-4 or Postinor-2, health care providers must not allow the apparent dissatisfaction with less effective methods to discourage condom use among former users of emergency contraception.

Preferences for emergency contraception products: The last issue to be addressed in the study was the overall attitude of emergency contraception users towards the methods themselves. Did fewer side effects correlate with a greater appreciation for the product; or with an increased likelihood that it would be recommended to friends and relatives?

To begin with, it is important to acknowledge that responses to questions on client satisfaction often serve as poor indicators of how clients truly feel about a product or service. The same may very well be true with the present data, which consist of responses to queries as to whether the client would ever recommend emergency contraception to a friend. Nevertheless, client histories once again showed only minor differences in the relative appeal of the two products. Of the 59 Postinor- 2 users who returned to follow up, only one said she would not recommend the method to a friend; the reason given being method failure. A slightly higher percentage of former PC-4 users (7 out of 209) said they would not recommend the method. In this case, the principal reason given was side effects and the failure to prevent pregnancy. In both cases, however, method approval exceeded 95 percent.

\section{Conclusions:}

The results of this study clearly show that there is little relationship between the side effects of an emergency contraception product, clients' responses to that method, and the demands on the service delivery system. Nor do the data support any of the theories associating the severity of side effects with either aversion to the method or a reduction in its repeat use.

In retrospect, the findings of this study could have even been stronger had the research design allowed for measuring repeat use directly, rather than relying on proxy variables such as return to follow-up and adoption/continuation of family planning methods. Because no such data was collected during the introduction of $P C-4$, however, there would have been no basis for comparison, even if the present design had been modified. But by the same token, the proxy variables used in this study are probably a more realistic indicators than repeat-use, of the kinds of differences likely to result from the use of the two methods. Why? Because the findings of a parallel study on prophylactic use of emergency contraception pills, suggest that repeat use typically derives from multiple factors ranging from accessibility to the method to an individual's current contraceptive behavior or even reproductive health circumstances (Skibiak et al 1999).

Another point worth noting, however, relates to the issue of repeat use and the rights of individuals to address their own individual reproductive health needs. Much of the literature on emergency contraception assumes that the most appropriate use of the method is in accordance with what its name implies - emergencies. In fact, it is precisely this assumption that underlies the fears and suspicions associated with a "more tolerable" or "side-effect free" emergency contraception method. The fact of the matter, however, is that for some women, repeat use of emergency contraception may very well be the most appropriate strategy to meet their own reproductive health circumstances. These may include women whose sexual activity is sporadic; women who prefer routine use of natural family planning methods; or 
even for women whose regularly use condoms, but occasionally experience breakage. For these women, the choice is not between emergency contraception and a "more effective method", it is between emergency contraception and an unwanted pregnancy, or even unsafe abortion. Providers must, therefore, be equipped to provide these with women with the information, services, and methods they request. 


\section{FROM RESEARCH TO ACTION: THE NEXT STEPS}

$W_{\text {hat, then, do the results of this study suggest about service delivery and behavioral }}$ implications of PC-4 and Postinor-2? Are they truly comparable? Are the lessons learned from having introduced one really comparable to the results of having introduced the other?

From a user-perspective, there is little doubt that despite the very distinctive nature of the two products, their effect on user attitudes and behavior has been virtually indistinguishable. At present, family planning users in Zambia display few preferences or aversions towards either product. They adopt both at comparable rates and, after having used them, manifest few if any differences in their appreciation of either product; in their decision to adopt a family planning method, or even in their choice of method itself.

From a provider-perspective, similarities also overshadow differences. Provider training was virtually identical for both methods, and indeed most of those trained to provide Postinor-2 had already been trained in emergency contraception either under Phase One of this project, or by CARE/Zambia as part of their program of technical support to the Zambia Central Board of Health. Even more important, however, the absence of differences in client attitudes and behavior would obviate any need for providers to vary their support to users of either method. Indeed, the only alarming trend to emerge from the use of emergency contraception that of eschewing barrier methods for more "effective" hormonal methods - was common to both methods.

And finally, from a service delivery perspective, recent policy decisions by Schering even call into question earlier assumptions that de-medicalizing emergency contraception would hinge on the selection of one product over the other. In June 1998, two months after the launching of this study, Schering bowed to pressure from the British Parliament by expanding the range of providers authorized to prescribe $P C-4$ to include nurses and pharmacists. Though this move does not go so far as to permit over the counter sales of the product, it still represents a major step forward in enhancing women's access to the product. And if indeed this policy should eventually be extended to Schering's operations worldwide, then the question of access may represent less of a rationale for exploring alternative emergency contraception products.

What then, should one conclude from these findings? Should one conclude that the programmatic differences associated with introducing progestin or Yuzpe regimens of emergency contraception are insignificant - perhaps even nonexistent? Throughout the study, the argument has consistently been made that the similarities between PC-4 and Postinor-2, at the service delivery level, greatly overshadow their differences. And, for all of the reasons cited above, this contention certainly holds true. But there are differences between the two products; some of which could very well have implications that go far beyond the service delivery aspects discussed here. 
One such difference relates to the issue of supply and logistics. Under this study, the procurement of $P C-4$ and Postinor-2 stocks was made possible through the financial support of Britain's Overseas Development Administration (now DfID) and WHO/HRP. From a service delivery perspective, therefore, product costs and the logistics of supplying commodities remained outside the present focus of inquiry. In the real world, however, and certainly from a programmatic perspective, costs and logistics are very much an issue. What is more, they are issues that affect progestin-only and combined oral contraceptives quite differently.

Technically speaking, $P C$-4 consists of nothing more than four of Schering's high-dose oral contraceptives, Neogynon, repackaged and marketed under a different brand name (Camp 1998: 225). Because the price of each tablet sold under the name $P C$-4 is many times more than that of a tablet contained in a full cycle of Neogynon, the fact remains that in the case of combined emergency contraception regimens, substitution is always an option - either by the same number of high dose contraceptives, or by doubling the number of low-dose pills. In the event of product stockouts or in an environment of cost cutting, $P C-4$ can always be replaced - and done so more cheaply - by existing supplies.

Postinor-2, by contrast, has no true equivalent within the range of methods typically available at health care facilities. One could, it is true, administer the same level of hormones by substituting 20-25 low-dose progestin-only oral contraceptive pills for each Postinor-2 tablet, but it has not been established whether the progestins contained in the brands currently available in Zambia (Microlut and Microval) would be metabolized in the same way (Ellertson 1998) or even whether women would be willing to ingest that many pills at one time. ${ }^{9}$ Furthermore, in contrast to $P C-4$, substitution would not provide any cost savings for the simple reason that the unit price (to donors) of one packet of Postinor-2 and that of a cycle of minipills is essentially the same.

There is, however, one final distinction to be made between PC-4 and Postinor-2 - a distinction that could not be addressed within this study, but one that would nevertheless merit attention in any comparison of the two products. It is the fairly solid body of evidence suggesting that in addition to reducing certain side effects, a levonorgestrel-only regimen of emergency contraception may actually be more effective than the Yuzpe method at averting pregnancies (Von Hertzen 1998: 222-232; Von Hertzen et al 1998: 1939). The decision not to compare the efficacy of the two regimens in this study was taken for two reasons. In the first place, a detailed comparison of the methods' technical attributes would clearly have fallen outside the present scope of inquiry, which was to gauge the service delivery implications of method introduction. Secondly, the need for such a study was mooted by the fact that WHO (Task Force 1998: 428-433) had already concluded a randomized, doubleblind study on this issue among 2,000 women in 14 countries. The results of this study, which were published three months after the start-up of the present study, confirmed the findings of previous research. They showed that the efficacy of levonorgestrel was greater than that of the Yuzpe regimen in terms of both crude and adjusted pregnancy rates and pregnancies prevented ${ }^{10}$.

\footnotetext{
9 It is worth noting, however, that in focus group discussions carried out among clients at the $P C$ - 4 clinics, women showed little aversion to the notion of ingesting 20-25 minipills, if doing so was to prove more effective at preventing pregnancy and less prone to side-effects than taking PC-4.

10 Crude pregnancy rates were 3.2 percent among those assigned to the Yuzpe regimen, compared to 1.1
} 
In 1998, von Hertzen concluded her review of alternative emergency contraception regimens by arguing that research had little value "if its results are not put into practice for the benefit of people". In looking beyond the purely technical attributes of the two emergency contraception products discussed here, this study has shown that the opportunities are wide open for making emergency contraception a reality for women. There are, it is true, substantive differences between the two products. The side effects are different; the efficacy may be different, and the implications for supply and logistics may be different. But perhaps most important of all is the fact that at the service delivery level, these differences do not call for new training programs, different client support mechanisms, or even distinctive strategies for the dissemination of information. Women display few preferences towards either product, they adopt both at comparable rates and, after having used them, manifest few if any differences in their decision to adopt a family planning method, or even in their choice of method itself. From the provider and service delivery perspective, similarities also overshadow differences.

What the findings of this study show therefore, is that the body of evidence collected to date on the service delivery implications of $P C-4$ is comparable and relevant to that associated with the delivery of Postinor-2. The challenge now, rests with Zambia's regulatory authorities to apply these lessons so that emergency contraception finally becomes a reproductive health option open to all women.

percent among those assigned levonorgestrel; while the proportion of pregnancies prevented (compared with the expected number without treatment) declined from 85 percent among women with the levonorgestrel regimen to 57 percent among those with the Yuzpe regimen (Task Force: 1998: 428). Comparing the WHO results with this study is complicated by the fact that the present study did not control for when during the participants' menstrual cycle unprotected sex occurred; nor did it exclude emergency contraception users who might have had unprotected sex more than once during the same cycle. Nevertheless, for informational purposes, only one Postinor-2 user (2 percent) became pregnant despite having taken the method within the first 72 hours of unprotected sex. This figure contrasts with 9 pregnancies among users of $P C-4$ (4.5 percent) - though all but one later admitted to having taken the method after 72 hours. In short, the study provided no basis for concluding that one regimen was any more effective than the other at preventing pregnancy. 


\section{REFERENCES}

Ahmed, Y., M. Ketata and J.P. Skibiak

1998 Emergency Contraception in Zambia: Setting a new agenda for research and action. Nairobi: The Population Council, Africa OR/TA II Project.

Camp, Sharon I.

1998 The Status of Dedicated Products. Journal of the American Medical Women's Association, Supplement 2. 53(5): 225.

Consortium for Emergency Contraception

1996 Emergency Contraceptive Pills: Commercial Product Development and Introduction in Developing Countries. Unpublished project proposal, April 1996.

Ellertson, Charlotte

1998 Personal communication, 13 December.

Ellis, Rachel

1998 EC pill on email. PA News. 111225 June 1998.

Glasier, A, KI Thong, M Dewar, M Mackie and DT Baird

1992 Mifepristone compared with high-dose estrogen and progestogen for emergency postcoital contraception. New England Journal of Medicine 327: 1041-1044.

Glasier, Anna and David Baird

1998 The effects of self-administering emergency contraception. New England Journal of Medicine 339(1): $1-4$

Ho, P.C. and Kwan, M.S.

1993 A prospective randomized comparison of levonorgestrel with the Yuzpe regimen in post-coital contraception. Human Reproduction 8: 389-392.

Hatcher, Robert A. et al.

1994 Contraceptive Technology, $16^{\text {th }}$ Revised Edition. New York: Irvington Publishers, Inc.

Simmons, Ruth, Peter Hall, Juan Diaz, Margarita Diaz, Peter Fajans, and Jay Satia

1997 The Strategic Approach to Contraceptive Introduction. Studies in Family Planning 28(2): 79-94.

Skibiak, JP, Y Ahmed and M Ketata

1999 Testing strategies to improve access to emergency contraception pills: Prescription vs. Prophylactic Distribution. Nairobi: The Population Council, Africa OR/TA II Project.

Task Force on Postovulatory Methods of Fertility Regulation

1998 Randomised controlled trial of levonorgestrel versus the Yuzpe regimen of combined oral contraceptives for emergency contraception. Lancet 352 (9126): 428-433.

von Hertzen, Helena

1999 Research on Mifepristone and Levonorgestrel in Comparison With the Yuzpe Regimen. Journal of the American Medical Women's Association, Supplement 2. 53(5): 222-232.

von Hertzen, Helena, G. Piaggio, and P.F.A.Van Look on behalf of the Task Force on Postovulatory Methods of Fertility Regulation

1998 Emergency contraception with levonorgestrel or the Yuzpe regimen. Lancet 352: 1939.

Webb, AMC, J Russell, and M Elstein

1992 Comparison of Yuzpe regimen, danazol and mifepristone (RU 486) in oral postcoital contraception. British Medical Journal 305: 927-931. 
